\title{
Etika Profesional Konsultan Pajak Dalam Melaksanakan Perannya Sebagai Mitra Wajib Pajak Dan Pemerintah
}

\author{
Rizki Arvita ${ }^{1}$ \\ Fakultas Ekonomi dan Bisnis \\ Universitas Airlangga, Indonesia \\ Email: rizkiarvita35@gmail.com
}

\author{
Tjiptohadi Sawarjuwono ${ }^{2}$ \\ Fakultas Ekonomi dan Bisnis \\ Universitas Airlangga, Indonesia
}

\begin{abstract}
ABSTRAK
Penelitian ini dilakukan dengan tujuan untuk menganalisis dan mendeskripsikan peran konsultan pajak dalam sistem perpajakan di Indonesia dan upaya yang dapat dilakukan untuk menjaga etika profesionalisme konsultan pajak sebagai mitra wajib pajak dan pemerintah. Jenis penelitian ini adalah deskriptif kualitatif menggunakan data sekunder tentang perpajakan yang diperoleh dari pencarian internet. Analisis data menggunakan teknik kualitatif dengan tahapan pengumpulan data, reduksi data, dan penarikan kesimpulan. Hasil penelitian mnejelaskan bahwa konsultan pajak berperan penting dalam sistem perpajakan, yaitu sebagai komponen perpajakan yang berkemampuan menjaga stabilitas, interaksi yang sehat dan dinamis antara wajib pajak dan pemerintah sesuai dengan peraturan pajak yang ditetapkan oleh pemerintah. Pemerintah sebagai otoritas pajak perlu melakukan upaya intervensi pada pelaksanaan peran konsultan pajak untuk memastikan bahwa konsultan pajak mematuhi kode etik profesi, sehingga dapat meningkatkan peran konsultan pajak dalam menciptakan dan mendorong kepatuhan wajib pajak terhadap peraturan perpajakan Indonesia.
\end{abstract}

Kata Kunci: Konsultan Pajak; Kode Etik; Profesionalisme.

\section{Professional Ethics Of Tax Consultants In Implementing Their Role As A Tax And Government Mandatory Partner}

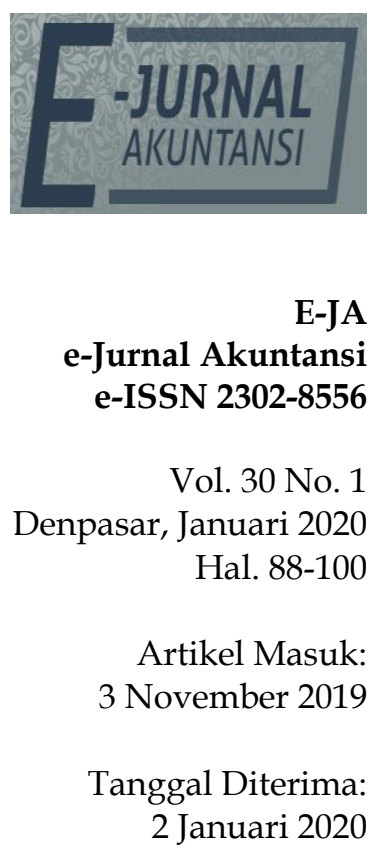

This research aims to analyze and describe the role of tax consultants in the taxation system in Indonesia and the efforts that can be made to maintain the ethics of professionalism of tax consultants as taxpayer partners and the government. This type of research is descriptive qualitative by using secondary data about taxation obtained from internet searches. Data analysis uses qualitative techniques with stages of data collection, data reduction, and taking conclusions. The results stated tax consultants play an important role in the taxation system in Indonesia, namely as a tax component, which is capable of maintaining stability, healthy and dynamic interaction between taxpayers and the government in accordance with tax regulations established by the government. The government as a tax authority needs to intervene in the implementation of the role of tax consultants to ensure that tax consultants comply with the professional code of ethics, so as to increase the role of tax consultants in creating and encouraging taxpayer compliance with Indonesian taxation regulations.

Keywords: Tax Consultant; Code of Ethics; Professionalism. 


\section{PENDAHULUAN}

Pajak menjadi target sumber penerimaan negara terbesar sejak APBN 1998/1999 (Budileksmana, 2015). Realisasi atas target tersebut terbukti melalui capaian penerimaan negara dari sektor pajak hingga Oktober 2019 sebesar Rp 1.018,5 triliun atau 64,56\% dari target Rp 1.577,56 triliun, yang mengalami pertumbuhan sebesar 0,23\% (Julita, 2019). Meskipun demikian, negara sebenarnya masih dapat lebih mengoptimalkan penerimaan dari sektor pajak jika mampu meminimalisir atau bahkan menghilangkan terjadinya kecurangan pajak.

Besarnya kecurangan pajak di Indonesia bahkan diprediksi oleh Forum Indonesia untuk Transparansi Anggaran (FITRA) mencapai sekitar Rp110 pertahunnya (Himawan, 2017). Data ini sesuai dengan data yang diolah oleh International Center for Taxation and Development (ICTD), yang menetapkan Indonesia sebagai negara peringkat 11 penghindaran pajak terbesar dengan besar penghindaran pajak mencapai sekitar Rp91,925 triliun pada tahun 2016 (Simanjuntak, 2017).

Tugas untuk mengoptimalkan penerimaan pajak dengan cara menekan terjadinya kecurangan pajak memang bukan tugas yang mudah. Selain dihadapkan pada faktor jumlah wajib pajak yang sangat besar, faktor sistem kalkulasi pajak yang bersifat self assessment juga menghadirkan beragam permasalahan yang kompleks. Sistem pemungutan pajak self assessment adalah sistem pemungutan pajak yang memberikan tanggung jawab perhitungan, pembayaran, dan pelaporan pajak kepada wajib pajak. Peran pemerintah dalam sistem tersebut adalah sebagai pengawas yang akan mengambil tindakan jika terjadi kesalahan pada wajib pajak, misalnya telat lapor pajak atau telat membayar pajak terutang.

Sistem self assessment menuntut peran aktif dari wajib pajak untuk mengurus perpajakannya. Meskipun hal ini memberikan kemudahan bagi pemerintah, yaitu tidak perlu melakukan perhitungan pajak bagi setiap wajib pajak untuk pajak tertentu yang menggunakan sistem self assessment, namun sistem ini juga memiliki celah yang memungkinkan wajib pajak melakukan analisis dan perhitungan dengan tujuan untuk dapat menekan besar pajak yang harus dibayarkan. Dalam hal ini, wajib pajak yang pada umumnya tidak memiliki pengetahuan mendalam mengenai regulasi perpajakan seringkali menggunakan jasa konsultan pajak untuk mengurus masalah perpajakannya.

Sesuai dengan ketetapan pemerintah yang dituangkan dalam Keputusan Menteri Keuangan no. 485/KMK.03/2003, konsultan pajak adalah "setiap orang yang dalam lingkungan pekerjaannya secara bebas memberikan jasa profesional kepada Wajib Pajak dalam melaksanakan hak dan kewajiban perpajakannya sesuai dengan peraturan perundang-undangan perpajakan yang berlaku". Menurut pengertian tersebut, maka konsultan pajak adalah pihak yang memiliki peran penting dalam mengedukasi dan membantu wajib pajak untuk menunaikan kewajban pajaknya sesuai dengan regulasi perpajakan yang berlaku. Dengan demikian, peran konsultan pajak secara teoritis adalah lebih sebagai pendukung otoritas pajak dalam memastikan bahwa wajib pajak memahami dan menaati peraturan perpajakan. Namun dalam praktiknya, interaksi kerjasama antara konsultan pajak dan wajib pajak dapat juga menciptakan kesempatan untuk terjadinya kecurangan pajak. 
Pajak sebagai sebuah kewajiban bagi setiap wajib pajak kepada negara perlu untuk dikelola dengan baik. Dalam pengelolaannya, pemerintah diwakili oleh Direktorat Jenderal Pajak yang bertugas untuk memastikan bahwa wajib pajak telah menunaikan berbagai kewajiban pajaknya kepada negara. Namun demikian, dalam pelaksanaan pembayaran pajak, terkadang wajib pajak menemui beragam kendala, misalnya terkait dengan besar pajak yang harus dibayarkan atau terkait dengan jenis pajak apa saja yang menjadi kewajibannya. Untuk itu, diperlukan adanya masukan-masukan atau nasehat kepada wajib pajak untuk mengatasi masalah-masalah tersebut. Dalam hal ini, peran dari konsultan pajak sangat diperlukan, baik bagi wajib pajak untuk mengatasi masalah yang dihadapi, baik bagi pemerintah untuk mengefisienkan perhitungan besar pajak yang harus dibayar oleh wajib pajak.

Konsultan pajak memiliki peran sebagai perantara bagi wajib pajak dan otoritas pajak berkaitan dengan pemenuhan beban pajak oleh wajib pajak sesuai dengan regulasi perpajakan yang berlaku. Di satu sisi, konsultan pajak dapat menjadi pendukung wajib pajak dalam memahami beban pajaknya dengan mengacu pada peraturan pajak yang harus ditaati, sedangkan di sisi lain, konsultan pajak juga dapat menjadi pihak yang memastikan bahwa pungutan pajak oleh otoritas pajak telah dilakukan sesuai dengan perundang-undangan terkait (Komara, 2014).

Jika mengacu pada Peraturan Menteri Keuangan (PMK) No. 111/PMK.03/2014, maka konsultan pajak adalah pihak yang berprofesi sebagai pemberi masukan mengenai perpajakan kepada wajib pajak melalui jasa konsultasi untuk memastikan wajib pajak mendapatkan haknya dan memenuhi kewajiban pajaknya dengan tepat sesuai dengan regulasi perpajakan yang berlaku. Konsultan pajak pada umumnya dapat memberikan enam jenis jasa konsultasi, yaitu terkait dengan tax management, tax review, tax compliance, tax litigation, tax research, dan tax administration.

Dalam mendukung peran yang optimal, pihak konsultan pajak juga perlu memiliki sikap professional dan komitmen. Pengertian komitmen profesional dapat diketahui dengan merujuk pada pengertian dari istilah-istilah pembentuknya, yaitu komitmen dan profesional. Komitmen artinya tanggung jawab dan kesungguhan dalam menepati janji yang telah disampaikan. Komitmen dapat tertuju pada diri sendiri maupun pihak lain. Komitmen pada diri sendiri berarti kesungguhan untuk memenuhi janji atau target yang telah ditetapkan untuk dicapai, disertai tanggung jawab penuh terhadap segala konsekuensi yang akan didapatkan berkaitan dengan hal tersebut. Komitmen terhadap pihak lain, misalnya terhadap organisasi atau terhadap profesi tertentu yang dimiliki berarti kesungguhan untuk mencapai sasaran yang diembankan, melalui upaya-upaya yang mengacu pada ketetapan yang diberikan, serta tanggung jawab terhadap dampak-dampaknya (Deepak, 2016).

Profesional berasal dari kata dasar profesi, yang artinya bidang pekerjaan tertentu yang membutuhkan kualifikasi pendidikan dan keterampilan spesifik untuk dapat melaksanakan tugas dan tanggung jawab yang diembankan dalam profesi tersebut. Profesional merujuk pada pihak yang mampu melaksanakan 
berbagai tuntutan profesi dengan baik, atau paling tidak memenuhi standar pelaksanaan atau capaian yang diharapkan.

Berdasarkan arti dari komitmen dan profesional tersebut, maka komitmen profesional berarti tanggung jawab dan kesungguhan seorang profesional terhadap beban kerja atau target yang harus dipenuhi oleh bidang pekerjaannya. Komitmen profesional dapat tergambar pada loyalitas kerja, kinerja unggul, atau totalitas dalam upaya mencapai tujuan profesi (Harmana, Wirakusuma, \& Wirama, 2017).

Komitmen profesional tercermin dalam tiga hal yang ada pada diri seorang konsultan pajak, yaitu: (1) Adanya penerimaan dan keyakinan terhadap nilainilai dan tujuan yang ingin dicapai oleh profesinya; (2) Adanya keinginan untuk melakukan upaya semaksimal mungkin demi kepentingan profesi; dan (3) Adanya keinginan untuk tetap menjadi bagian dari profesi (Aziz, Subroto, \& Subekti, 2016). Komitmen profesional dapat juga terlihat pada kepatuhan individu terhadap sistem, peraturan, dan segala kebijakan yang ditetapkan dalam profesinya, yang dilandasi oleh keinginan dan upaya keras demi mencapai tujuan atau target profesi yang diberikan (Arifah \& Romadhon, 2015).

Berkaitan dengan profesi pada konsultan pajak, pada dasarnya setiap profesi memiliki peraturan tersendiri yang berupaya mengikat setiap aktivitas yang berkaitan dengan profesi tersebut agar sesuai dengan nilai-nilai dan tujuan yang ingin dicapai. Selain berbentuk regulasi formal yang memiliki sanksi secara pasti, peraturan tersebut dapat juga berwujud seperangkat nilai moral yang ditetapkan sebagai acuan berperilaku bagi individu yang menekuni profesi yang berkaitan. Nilai-nilai moral tersebut pada umumnya disebut dengan istilah etika profesi (Darmayasa \& Aneswari, 2015).

Etika merupakan kata serapan dari Bahasa Yunani "ethos", yang artinya adalah cara berpikir, sikap, perasaan, sifat, kebiasaan, atau adat. Secara normatif, etika berarti nilai moral yang menjadi acuan dalam menentukan suatu hal layak atau tidak layak, harus dilakukan atau tidak boleh dilakukan. Lebih lanjut, etika dapat juga dimaknai sebagai prinsip moral yang dijadikan dasar untuk bersikap dan bertindak untuk menciptakan nilai positif (Murtanto \& Marini, 2003).

Menurut Koerniawan (2013), etika profesi menjadi pembeda antar berbagai profesi karena etika profesi membentuk ciri-ciri khusus yang hanya dimiliki oleh satu jenis profesi. Ciri-ciri khusus tersebut terlihat dari bagaimana anggota yang tergabung dalam profesi bersikap dan berperilaku dalam kesehariannya ketika melaksanakan aktivitas-aktivitas yang berkaitan dengan profesinya.

Berdasarkan penjelasan di atas, maka penelitian ini dilakukan untuk menjawab dua rumusan masalah, yaitu: Bagaimana peran konsultan pajak dalam sistem perpajakan di Indonesia dan upaya yang dapat dilakukan untuk menjaga etika profesionalisme konsultan pajak sebagai mitra wajib pajak dan pemerintah?. Sesuai dengan rumusan masalah tersebut, maka tujuan penelitian ini adalah untuk: Menganalisis dan mendeskripsikan peran konsultan pajak dalam sistem perpajakan di Indonesia dan upaya upaya yang dapat dilakukan untuk menjaga etika profesionalisme konsultan pajak sebagai mitra wajib pajak dan pemerintah. 


\section{METODE PENELITIAN}

Penelitian ini adalah penelitian deskriptif dengan pendekatan kualitatif. Penelitian deskriptif adalah penelitian yang berupaya menggambarkan suatu keadaan yang menjadi fokus penelitian, kemudian menjelaskan keadaan tersebut berdasarkan data-data yang ditemukan dan berbasis analisis yang dilakukan (Arikunto, 2016). Adapun pendekatan kualitatif adalah pendekatan penelitian yang menggunakan model analisis induktif untuk mengkaji pokok permasalahan yang diteliti, untuk kemudian memaparkannya menggunakan uraian bahasa sesuai dengan pemikiran peneliti berdasarkan data-data yang ditemukan (Moleong, 2012). Sedangkan datanya berupa data sekunder yang diperoleh dari sumber lain yang telah secara langsung mengumpulkan data di lapangan dan menggunakan tiga tahapan teknik analisis data berupa pengumpulan data, pengurangan data dan penarikan kesimpulan.

\section{HASIL DAN PEMBAHASAN}

Pajak masih menjadi sumber pemasukan pendapatan negara yang dominan. Kontribusi pajak dari tahun ke tahun terus menunjukkan peningkatan dengan rata-rata kontribusi mencapai $70 \%$ dari penerimaan negara tiap tahunnya. Hal ini dapat dilihat pada data Kementrian Keuangan (kemenkeu) sebagai berikut:

\section{Tabel 1. Kontribusi Pajak terhadap Pendapatan Negara}

\begin{tabular}{cccc}
\hline Tahun & $\begin{array}{c}\text { Penerimaan Negara } \\
\text { (Triliun) }\end{array}$ & $\begin{array}{c}\text { Penerimaan Pajak } \\
\text { (Triliun) }\end{array}$ & $\begin{array}{c}\text { Persentase } \\
\text { Pajak (\%) }\end{array}$ \\
\hline 2008 & 981,6 & 571,1 & $58,2 \%$ \\
2009 & 848,8 & 544,5 & $64,1 \%$ \\
2010 & 995,3 & 628,2 & $63,1 \%$ \\
2011 & 1210,6 & 742,7 & $61,3 \%$ \\
2012 & 1338,1 & 835,8 & $62,5 \%$ \\
2013 & 1438,9 & 921,4 & $64,0 \%$ \\
2014 & 1550,6 & 985,1 & $63,5 \%$ \\
2015 & 1761,6 & 1294,3 & $73,5 \%$ \\
2016 & 1786,2 & 1539,1 & $86,2 \%$ \\
2017 & 1736,06 & 1472,7 & $84,8 \%$ \\
2018 & 1894,7 & 1618,1 & $85,4 \%$ \\
& Rata-rata & & $69,7 \%$ \\
\hline
\end{tabular}

Sumber: Kementrian Keuangan RI, 2018

Data pada Tabel 1. menunjukkan besarnya penerimaan negara dari sektor pajak yang belum bisa diimbangi oleh penerimaan dari sektor non pajak. Hal ini menjelaskan pentingnya pajak bagi negara, sehingga upaya untuk dapat memaksimalkan penerimaan pajak selalu menjadi prioritas utama bagi pemerintah. Namun demikian, permasalahan yang selalu mengemuka pada setiap tahunnya adalah terkait dengan besarnya penghindaran pajak, baik oleh wajib pajak berupa badan usaha maupun perseorangan.

Menurut data yang diolah oleh International Center for Taxation and Development (ICTD), Indonesia berada peringkat ke 11 dari 30 negara dengan penghindaran pajak terbesar pada tahun 2016. Selengkapnya data tersebut adalah sebagai berikut (Simanjuntak, 2017). 
Tabel 2. Peringkat Penghindaran Pajak Negara di Dunia Tahun 2016

\begin{tabular}{ccc}
\hline Peringkat & Negara & $\begin{array}{c}\text { Besar Penghindaran Pajak } \\
\text { (Dalam Miliar Dollar) }\end{array}$ \\
\hline 1 & Amerika Serikat & 188,8 \\
2 & China & 66,8 \\
3 & Jepang & 46,7 \\
4 & India & 41,1 \\
5 & Malaysia & 23,3 \\
6 & Argentina & 21,4 \\
7 & Perancis & 19,7 \\
8 & Jerman & 15 \\
9 & Dominika & 11,7 \\
10 & Pakistan & 10,4 \\
11 & Indonesia & 6,48 \\
\hline
\end{tabular}

Sumber: Simanjuntak, 2017

Pada Tabel 2. diketahui jumlah penghindaran pajak di Indonesia menduduki peringkat 11 dengan nilai sebesar 6,48 miliar dollar atau sekitar 91,925 triliun rupiah (1 dolar sama dengan 14.186 rupiah) adalah sangat besar. Apabila negara dapat meminimalisir atau menghilangkan penghindaran pajak tersebut, maka pendapatan dari sektor pajak akan dapat lebih optimal. Dengan demikian dapat diketahui bahwa besar pajak yang dapat diterima oleh pemerintah Indonesia sebenarnya dapat lebih besar jika pemerintah dapat menerapkan strategi yang mampu menurunkan penghindaran pajak. Hal ini tentu membutuhkan kolaborasi antara pemerintah dan wajib pajak, maupun pihak lainnya yang terlibat seperti konsultan pajak.

Di Indonesia terdapat organisasi konsultan pajak yang dikenal dengan nama Ikatan Konsultan Pajak Indonesia (IKPI). IKPI didirikan pada tanggal 27 Agustus 1965 sebagai sebuah organisasi konsultan pajak. Kegiatan IKPI mulai aktif pada sekitar 1970-an, mulai dari diselenggarakannya kongres pertama di Jakarta pada tanggal 31 Oktober 1975 dengan hasil pemberian nama Ikatan Konsulen Pajak Indonesia. Nama tersebut selanjutnya dirubah menjadi Ikatakan Konsultan Pajak Indonesia (IKPI) melalui kongres pada tanggal 21 Nopember 1987 (Ikatan Konsultan Pajak Indonesia, 2019).

IKPI merupakan sebuah organisasi yang bersifat mandiri, berorientasi pada pelayanan publik, dan bersifat independen. Visi IKPI adalah untuk menjadi organisasi pajak kelas dunia. Misi IKPI adalah memelihara perdamaian dengan memperbaiki hubungan internal dan eksternal serta menjalin kerjasama (mitra) dengan Direktorat Jenderal Pajak (DJP), Kamar Dagang dan Industri (KADIN) serta dunia internasional. Tujuan dari IKPI antara lain adalah meningkatkan peranan IKPI melalui anggotanya dalam membantu setiap program pemerintah berkaitan dengan bidang perpajakan, meningkatkan mutu pengetahuan anggota IKPI, memperjuangkan dan melindungi kepentingan anggotanya dalam menjalankan profesinya. Berbagai kegiatan yang diselenggarakan oleh IKPI antara lain menyelenggarakan seminar, ceramah, lokakarya, diskusi, PPL (Pengembangan Profesional Berkelanjutan), atau kegiatan sejenis untuk meningkatkan pengetahuan anggota dan masyarakat Wajib Pajak, menyelenggarakan perpustakaan, dokumentasi dan penerbitan, menyediakan informasi perpajakan bagi anggota, membuat pedoman tentang sikap dan tata cara anggotanya dalam melaksanakan profesinya dan melakukan penyesuaian 
sesuai perkembangan lingkungan, memperjuangkan peningkatan ruang lingkup profesi Konsultan Pajak, melakukan penelitian dan pengkajian di bidang perpajakan, melaksanakan pengawasan dan penetapan sanksi terhadap pelanggaran disiplin dan Kode Etik IKPI, memelihara dan memupuk hubungan serta kerjasama yang lebih baik dengan pemerintah, dunia usaha dan masyarakat luas, berperan serta dalam forum internasional di bidang perpajakan, antara lain dalam bentuk seminar, konferensi, pertukaran informasi, dan lain sebagainya; dan (10) melakukan kegiatan dan usaha lain yang tidak bertentangan dengan Anggaran Dasar (AD) dan Anggaran Rumah Tangga (ART).

Sebagai sebuah lembaga publik, IKPI memiliki kode etik yang ditetapkan untuk memastikan setiap anggotanya melaksanakan tugas pelayanan terbaik dalam bidang perpajakan. Kode etik IKPI merupakan kaidah moral yang menjadi pedoman dalam berfikir, bersikap dan bertindak bagi setiap anggota IKPI dan mengatur sanksi terhadap pelanggaran Kode Etik IKPI, dimana setiap anggota IKPI wajib menjaga citra dan martabat profesi dengan senantiasa berpegang pada Kode Etik IKPI.

Menurut Anggaran Dasar (AD) IKPI, kode etik konsultan pajak dibagi menjadi 4 bab, yaitu berkaitan dengan kepribadian konsultan pajak; hubungan dengan teman seprofesi; hubungan dengan wajib pajak; dan terkait publikasi. Selain mengatur mengenai kode etik konsultan pajak, AD IKPI juga menetapkan sanksi-sanksi yang dapat dikenakan jika konsultan pajak terbukti melanggar kode etik tersebut. Pihak yang diberikan wewenang untuk melakukan pemeriksaan dan penetapan sanksi terhadap konsultan pajak adalah Dewan Kehormatan melalu pembentukan Majelis Kehormatan. Sanksi yang dapat diberikan antara lain berupa teguran tertulis, pemberhentian sementara, dan pemberhentian tetap.

Sebagaimana dicantumkan dalam daftar aktivitas IKPI, maka setiap konsultan pajak memiliki peran sebagai salah satu komponen penting dalam sistem perpajakan Indonesia, yaitu sebagai penjaga dan pemelihara interaksi yang stabil dan dinamis antara wajib pajak dan pemerintah. Dalam praktiknya, konsultan pajak mengedukasi wajib pajak untuk lebih memahami berbagai regulasi perpajakan yang ditetapkan otoritas pajak agar wajib pajak dapat memastikan semua haknya terpenuhi dan kewajibannya tertunaikan.

Konsultan pajak adalah pihak yang memiliki kompetensi di bidang perpajakan selain otoritas pajak. Berdasarkan hal tersebut, maka selain didasarkan pada tugas pekerjaannya, maka konsultan pajak juga memiliki beban moral untuk membantu wajib pajak dalam mengatasi berbagai permasalahan terkait perpajakan. Tidak dapat dipungkiri jika pajak dipandang sebagai beban oleh wajib pajak. Oleh karena itu, selalu terdapat kecenderungan pada diri wajib pajak untuk mencoba mengetahui secara pasti besar pajak yang harus dibayarkannya serta mencari kemungkinan untuk dapat mengefisienkan besar pajak tersebut. Dalam hal ini, wajib pajak membutuhkan peran dari konsultan pajak yang memahami secara mendalam mengenai perundang-undangan perpajakan yang ditetapkan pemerintah untuk mengkaji beban pajak apa saja serta besar pajak yang harus ditunaikan oleh wajib pajak (Arestanti, Herawati, \& Rahmawati, 2017). 
Penerapan metode perhitungan pajak secara self assessment di Indonesia mengharuskan setiap wajib pajak untuk berupaya memahami berbagai peraturan perpajakan yang cukup banyak dan terus mengalami perkembangan dari tahun ke tahun. Hal ini secara umum menghadirkan permasalahan mendasar bagi wajib pajak yang mayoritas bukan dari kalangan yang memiliki pemahaman detil dan jelas atas regulasi perpajakan. Solusi yang diterapkan oleh pemerintah untuk mengatasi masalah ini adalah dengan menghadirkan peran Account Representative (AR) yang diposisikan di setiap Kantor Pelayanan Pajak (KPP). Keberadaan AR tersebut diharapkan dapat membuat wajib pajak menjadi semakin memahami prosedur pajak yang berlaku, sehingga dapat meningkatkan efektivitas proses pembayaran pajak serta meningkatkan efisiensi biaya yang harus dikeluarkan wajib pajak dalam menunaikan kewajiban pajaknya. Namun demikian, muncul permasalahan terkait jumlah AR yang masih sangat sedikit, sehingga tidak mampu memenuhi kebutuhan wajib pajak atas informasi perpajakan secara menyeluruh (Munabari \& Aji, 2014).

Celah kebutuhan wajib pajak atas kejelasan berbagai hal yang berkaitan dengan perpajakan tersebut menghadirkan kesempatan besar bagi peran entitas legal yang memiliki kompetensi terkait perpajakan, yaitu konsultan pajak. Namun demikian, perlu tetap dipahami bahwa konsultan pajak bukan merupakan pihak yang berada di sisi wajib pajak dalam menghadapi permasalahan pajak. Konsultan pajak adalah komponen penting dari otoritas pajak, meskipun tidak berada dalam payung lembaga dengan legalitas sama, yang berperan untuk menjadikan wajib pajak semakin teredukasi dan mampu memenuhi kewajiban pajaknya dengan baik (Sutanto \& Tjondro, 2013).

Dengan demikian dapat dipahami bahwa konsultan pajak berdiri dengan dua kaki yang masing-masing kaki berpijak berada pada pihak yang berbeda. Konsultan pajak di satu sisi menjadi pemberi solusi atas permasalahan yang dihadapi oleh wajib pajak dan di sisi lain menjadi bagian dari otoritas pajak dalam memastikan bahwa wajib pajak telah menunaikan kewajiban pajaknya dengan benar. Peran ini sangat dibutuhkan baik oleh wajib pajak maupun oleh pemerintah dalam rangka menciptakan interaksi antara wajib pajak dan pemerintah yang stabil, dinamis, dan sehat dalam sistem perpajakan nasional.

Keberadaan otoritas pajak dan konsultan pajak diharapkan untuk dapat saling melengkapi sistem perpajakan Indonesia yang bersifat self assessment yang menuntut partisipasi aktif wajib pajak dalam menganalisis, menghitung, dan membayar pajaknya sendiri. Jika mengacu pada Pasal 11 Keputusan Menteri Keuangan RI No. 294/KMK.04/1998, maka dapat diketahui beberapa kewajiban konsultan pajak, yaitu, wajib mematuhi semua ketentuan peraturan perundangundangan perpajakan yang berlaku, wajib memberikan jasa kepada Wajib Pajak agar melaksanakan hak-hak dan kewajiban perpajakannya sesuai dengan peraturan perundang-undangan perpajakan yang berlaku, wajib mengikuti prosedur dan tata tertib kerja yang berlaku di lingkungan Direktorat Jenderal Pajak dan dilarang melakukan tindakan-tindakan yang merugikan kepentingan negara, dan wajib mengikuti penataran/pendidikan penyegaran perpajakan sekurang-kurangnya sekali dalam setahun.

Berdasarkan kewajiban-kewajiban konsultan pajak di atas, maka dapat diketahui bahwa kedudukan konsultan pajak sebenarnya tidak hanya sebagai 
mitra dari wajib pajak saja, namun juga merupakan mitra dari pemerintah. Namun demikian, sistem perpajakan yang bersifat self assessment memungkinkan terjadinya interaksi dan kerjasama antara wajib pajak dan konsultan pajak yang sangat bebas, baik dalam melakukan analisis terhadap beban pajak dari wajib pajak sekaligus dalam memilih metode pembayaran pajak yang tentu saja cenderung berorientasi pada kepentingan wajib pajak yang ingin membayar pajak dengan jumlah yang serendah-rendahnya. Kecenderungan tersebut selain didasarkan pada persepsi wajib pajak atas pajak yang sebagai beban yang harus dibayarkan, juga pada sistem self assessment yang seolah memberikan kesempatan untuk upaya pembayaran pajak seminimal mungkin (FrecknallHughes \& Kirchler, 2015).

Menghadapi situasi tersebut, konsultan pajak memang berada pada posisi yang dilematis. Perannya yang diharapkan dapat menciptakan dan meningkatkan kesadaran serta kepatuhan wajib pajak terhadap regulasi pemerintah terkait perpajakan seringkali dihadapkan pada kepentingan wajib pajak yang menjadi mitranya, yang menuntut konsultan pajak untuk bisa melakukan analisis untuk menekan besar beban pajak yang harus dibayarkan oleh wajib pajak. Untuk menjaga agar pelaksanaan peran konsultan pajak tetap berada pada prosedur yang tepat, maka terdapat kode etik yang harus dipatuhi oleh konsultan pajak (Budileksmana, 2015).

Kode etik konsultan pajak merupakan etika profesi atau nilai-nilai yang harus dijadikan acuan oleh setiap konsultan pajak dalam berperilaku dan beraktivitas melaksanakan perannya dalam sistem perpajakan di Indonesia. Melalui rumusan kode etik konsultak pajak, IKPI mengatur bagaimana setiap konsultan harus bertindak, berinteraksi dengan sesama konsultan dan dengan mitra kerja, serta dalam melakukan beragam jenis publikasi yang berkaitan dengan tugas konsultan pajak. Berdasarkan kepatuhan terhadap kode etik tersebut, maka konsultan pajak akan dapat menempatkan perannya sebagai penghubung antara wajib pajak dan otoritas pajak tanpa ada tendensi untuk berpihak atau berorientasi untuk mendahulukan kepentingan salah satu pihak saja.

Kepatuhan terhadap kode etik merupakan salah satu bentuk profesionalisme. Dalam hal ini, seorang konsultan pajak yang memiliki komitmen terhadap profesinya, atau dapat disebut sebagai konsultan pajak yang profesional, akan menerima, meyakini, dan melaksanakan semua ketentuan yang tertuang dalam kode etik konsultan pajak. Selain menjadi sebuah kesadaran moral, kepatuhan tersebut juga didasarkan pada adanya sanksi-sanksi yang akan dikenakan kepada konsultan pajak yang terbukti melanggar kode etik.

Dalam praktik kerja nyata konsultan pajak, pelanggaran terhadap kode etik profesi konsultan akan dapat berimplikasi pada terjadinya pelanggaran terhadap regulasi perpajakan, yaitu dalam bentuk kecurangan pajak. Kemungkinan terjadinya hal ini semakin besar jika ditambah dengan faktor ketiga yang terlibat selain wajib pajak dan konsultan pajak, yaitu petugas pajak yang berkompromi untuk menurunkan besar pajak yang harus ditunaikan wajib pajak kepada negara (Mangoting, Sukoharsono, \& Nurkholis, 2017).

Beberapa kasus penggelapan pajak yang terjadi akibat adanya ketidapatuhan konsultan pajak terhadap kode etik profesi pernah terjadi di 
Indonesia, misalnya kasus penggelapan pajak oleh konsultan pajak yang bekerja sama dengan petugas pajak pada tahun 2014 di Jakarta Timur. Kasus ini berawal pada tindakan konsultan pajak yang menawarkan kepada perusahaan wajib pajak yang menjadi mitranya, bahwa konsultan pajak tersebut mampu menurunkan besar biaya pajak yang harus dibayarkan perusahaan kepada negara. Berdasarkan kesepakatan antar keduanya, selanjutnya konsultan pajak bekerja sama dengan petugas pajak untuk membuat faktur fiktif, sehingga pajak yang dibayarkan oleh perusahaan tidak diberikan kepada negara namun dipergunakan untuk kepentingan pribadi dari konsultan pajak dan petugas pajak yang terlibat. Akibat kecurangan tersebut, negara mengalami kerugaian sebesar Rp 495 juta (Suparman, 2014).

Kasus kecurangan pajak lainnya juga terjadi pada tahun 2014, dimana seorang konsultan pajak melakukan penipuan terhadap sebuah perusahaan yang menjadi mitranya dengan cara menyalahgunakan pajak yang dibayarkan oleh perusahaan tersebut untuk kepentingan pribadinya. Konsultan pajak yang telah dipercaya oleh perusahaan untuk menangani laporan pajak perusahaan ternyata tidak membayarkan pajak perusahaan setiap bulannya, sehingga perusahaan tersebut dikenakan sanksi oleh KPP berupa pencabutan surat pengukuran pengusaha kena pajak. Perusahaan yang meyakini telah taat regulasi pajak dengan cara rutin membayar pajak lewat konsultan pajak akhirnya melaporkan penggelapan uang pajak oleh konsultan pajaknya (Direktorat Jenderal Pajak, 2019).

Dua kasus kecurangan pajak di atas menunjukkan dampak negatif yang sangat merugikan negara dari ketidakpatuhan konsultan pajak terhadap kode etik profesi. Selain karena adanya intensi dari wajib pajak yang menginginkan besar pajak seminimal mungkin yang harus dibayar, faktor petugas pajak juga mendukung kemungkinan terjadinya kecurangan pajak yang dilaksanakan oleh konsultan pajak. Oleh karena itu, untuk dapat menjaga agar konsultan pajak benar-benar menjalankan peran ganda sebagai mitra wajib pajak dan pemerintah secara profesional, maka perlu adanya upaya komprehensif dari pemerintah seperti melakukan sinergi dengan IKPI untuk melakukan pengawasan terhadap aktivitas konsultan pajak, meningkatkan peran aktif dari Account Representative (AR) dalam mengedukasi dan membantu wajib pajak menyelesaikan berbagai permasalahan perpajakannya, dan mengintegrasikan sanksi pelanggaran kode etik konsultan pajak ke dalam hukum, sehingga pelanggaran kode etik konsultan pajak tidak hanya dikenakan sanksi sesuai yang ditetapkan dalam AD IKPI, namun juga sanksi pidana maupun perdata. Hal ini tentu didasarkan pada implikasi dari pelanggaran kode etik yang secara nyata merugikan negara

Upaya-upaya di atas mengindikasikan adanya intervensi tinggi dari pemerintah terhadap pelaksanaan kerja dari konsultan pajak. Hal ini pada dasarnya memang sangat diperlukan karena adanya celah besar terjadinya kecurangan pajak yang melibatkan konsultan pajak. Dengan kata lain, konsultan pajak dapat menjadi komponen perpajakan yang berperan besar dalam membuat wajib pajak menjadi patuh terhadap regulasi perpajakan jika konsultan pajak tersebut mampu menjaga profesionalismenya dalam bentuk kepatuhan terhadap kode etik profesi. Sebaliknya, konsultan pajak justru dapat menjadi inisiator terjadinya kecurangan pajak karena pengetahuan konsultan pajak yang 
mendalam terhadap regulasi perpajakan berikut celah-celahnya yang tanpa disertai kepatuhan terhadap kode etik konsultan pajak. Pada dasarnya, profesionalisme konsultan pajak hanya akan terbentuk ketika konsultan pajak memiliki kepatuhan tinggi terhadap kode etik profesinya. Hal tersebut dapat terealisasi dengan adanya intervensi pemerintah sebagai otoritas pajak dalam memastikan bahwa pelaksanaan kerja konsultan pajak telah sesuai dengan regulasi perpajakan dan tidak menyalahi kode etik konsultan pajak.

\section{SIMPULAN}

Simpulan dari penelitian ini antara lain; pertama, konsultan pajak memiliki peran penting dalam sistem perpajakan di Indonesia, yaitu sebagai salah satu komponen perpajakan yang memiliki kemampuan untuk menjaga stabilitas interaksi antara wajib pajak dan otoritas pajak yang sehat dan dinamis sesuai dengan regulasi perpajakan yang ditetapkan oleh pemerintah. Kedua, konsultan pajak memiliki peran ganda, yaitu sebagai mitra pemerintah sekaligus wajib pajak. Namun demikian, pelaksanaan kerja konsultan pajak masih memungkinkan terjadinya praktik-praktik yang menyalahi kode etik profesi konsultan pajak yang dapat berujung pada timbulnya kerugian negara berupa terjadinya penggelapan pajak. Oleh karena itu, pemerintah sebagai otoritas pajak perlu melakukan upaya intervensi terhadap pelaksanaan peran konsultan pajak untuk memastikan bahwa konsultan pajak patuh terhadap kode etik profesinya, sehingga dapat meningkatkan peran konsultan pajak dalam menciptakan dan mendorong pertumbuhan kepatuhan wajib pajak terhadap regulasi perpajakan Indonesia.

Adapun saran penelitian yaitu dapat menindaklanjuti temuan penelitian ini dengan menggunakan data-data primer dari wawancara terhadap pihakpihak terkait, seperti Direktorat Jenderal Pajak, konsultan pajak, dan wajib pajak, untuk merumuskan strategi yang aplikatif untuk mendorong peningkatan kepatuhan konsultan pajak terhadap kode etik profesi, serta kepatuhan wajib pajak terhadap regulasi perpajakan.

\section{REFERENSI}

Arifah, D. A., \& Romadhon, C. (2015). Pengaruh Komitmen Organisasi, Komitmen Profesional dan Gaya Kepemimpinan terhadap Kepuasan Kerja dengan Motivasi sebagai Variabel Intervening. 2nd Conference in Business, Acounting, and Management, 2(357-369).

Arikunto, S. (2016). Prosedur Penelitian Suatu Pendekatan Praktik. Jakarta: Rineka Cipta.

Azis, A. N., Subroto, B. R., \& Subekti, I. (2016). Professional Commitment, Auditor Independence, and Organizational Ethical Culture: Empirical Evidence from Indonesia. International Journal of Management and Administrative Sciences (IJMAS), 3(9), 28-36.

Budileksmana, A. (2015). Manfaat dan Peranan Konsultan Pajak dalam Era Self Assessment Perpajakan. Jurnal Akuntansi \& Investasi, 1(2), 77-84.

Darmayasa, I. N., \& Aneswari, Y. R. (2015). The ethical practice of tax consultant based on local culture. Procedia-Social and Behavioral Sciences, 211, 142-148.

Deepak. (2016). Antecedent Value of Professional Commitment and Job 
Involvement in Determining Job Satisfaction. Management and Labour Studies, 41(2), 154-164.

Direktorat Jenderal Pajak. (2019). Pemeriksaan Pajak dan Sanksi Administrasi. Retrieved October 29, 2019 from pajak.go.id website: https://www.pajak.go.id/id/pemeriksaan-pajak-dan-sanksi-administrasi.

Frecknall-Hughes, J., \& Kirchler, E. (2015). Towards a General Theory of Tax Practice. Social \& Legal Studies, 24(2), 289-312.

Gade, M. (2005). Teori Akuntansi. Jakarta Timur: Penerbit Almahira.

Gunadi. (2004). Akuntansi Pajak: Sesuai dengan Undang-Undang Pajak Baru. Jakarta: Grasindo.

Harmana, I. M. D., Wirakusuma, M. G., \& Wirama, D. G. (2017). Pengaruh Idealisme, Pengalaman, dan Komitmen Profesional pada Pembuatan Keputusan Etis Konsultan Pajak Terdaftar di Wilayah Bali-Nusa Tenggara. E-Jurnal Ekonomi Dan Bisnis Universitas Udayana, 6(10), 3549-3577.

Himawan, A. (2017). Fitra: Setiap Tahun, Penghindaran Pajak Capai Rp110 Triliun. Retrieved October 29, 2019 from Suara.com website: https://www.suara.com/bisnis/2017/11/30/190456/fitra-setiap-tahunpenghindaran-pajak-capai-rp110-triliun.

Ikatan Konsultan Pajak Indonesia. (2019). Tentang Ikatan Konsultan Pajak Indonesia. Retrieved October 29, 2019 from ikpi.com website: from http://www.ikpi.or.id/content/tentang-kami.

Julita, L. (2019). Data dan Fakta Kinerja APBN Oktober 2019, Loyo. Retrieved December 21, 2019 from cnbcindonesia.com website: from https:/ / www.cnbcindonesia.com/news/20191119095653-4-116208/datadan-fakta-kinerja-apbn-oktober-2019-loyo.

Kementrian Keuangan Republik Indonesia. (2018). Informasi APBN 2018. Jakarta: Direktorat Jenderal Anggaran.

Koerniawan, K. A. (2013). Etika Profesi dalam Problematikan Di Era Kompetitif Menurut Sisi Pandang AKuntan Publik. Modernisasi, 9(1), 49-64.

Komara, A. (2014). Konsultan Pajak Agen Pemerintah atau Advokat Wajib Pajak. INdonesia Tax Review, VII(17).

Mangoting, Y., Sukoharsono, E. G., \& Nurkholis. (2017). Menguak DImensi Kecurangan Pajak. Jurnal AKuntansi Multiparadigma, 8(2), 274-290.

Moleong, L. J. (2012). Metode Penelitian Kualitatif Cet, Ke-30. Jakarta: Remaja Rosdakarya.

Muljono, D. (2010). Panduan Brevet Pajak: Akuntansi Pajak dan Ketentuan Umum Perpajakan. Yogyakarta: Penerbit Andi.

Munabari, F. W., \& Aji, A. W. (2014). Analisis Pengaruh Pengetahuan Perpajakan, Persepsi tentang Konsultan Pajak, dan Persepsi tentang Account Representative terhadap Minat dalam Menggunakan Jasa Konsultan Pajak pada Wajib Pajak Badan di KPP Pratama Bantul. Jurnal Akuntansi, 2(2), 6479.

Murtanto, \& Marini. (2003). Persepsi Akuntan Pria dan Akuntan Wanita serta Mahasiswa dan Mahasiswi Akuntansi terhadap Etika Bisnis dan Etika Profesi Akuntan. Prosiding Simposium Nasional Akuntansi, VI, 790-805.

Simanjuntak, J.. (2017). Indonesia Masuk Peringkat ke-11 Penghindaran Pajak Perusahaan, Jepang No.3. Retrieved October 29, 2019 from tribunnews.com 
website:

http://www.tribunnews.com/internasional/2017/11/20/indonesiamasuk-peringkat-ke-11-penghindaran-pajak-perusahaan-jepang-no3

Sugiyono. (2012). Metode Penelitian Kuantitatif Kualitatif Dan RED (Alfabeta). Bandung.

Sutanto, L., \& Tjondro, E. (2013). Persepsi Wajib Pajak terhadap Konsultan Pajak dan Preferensi Wajib Pajak dalam Memilih Konsultan Pajak: Honest Consultant, Creative Consultant, dan Cautious Consultant. Tax $\mathcal{E}$ Accounting Review, 3(2).

Suparman, F. (2014). Lagi, 2 Penggelap Pajak Dijebloskan ke Rutan Cipinang. Retrieved October 29, 2019 from beritasatu.com website: from https://www.beritasatu.com/nasional/226178/lagi-2-penggelap-pajakdijebloskan-ke-rutan-cipinang. 